\title{
Racionalidade Neoliberal E Política Pública Urbanística Frente Ao Direito De Participação Popular: Uma Análise Da ADI 0303489-40.2012.8.05.0000
}

\author{
Domingos do Nascimento Nonato* \\ Universiadade Federal do Pará, Programa de Pós-Graduação em Direito, Belém-PA, Brasil. \\ (iD) https://orcid.org/0000-0001-7194-9457 \\ Raimundo Wilson Gama Raiol** \\ Universiadade Federal do Pará, Programa de Pós-Graduação em Direito, Belém-PA, Brasil. \\ iD https://orcid.org/0000-0003-2407-1375 \\ Romário Edson da Silva Rebelo*** \\ Universiadade Federal do Pará, Programa de Pós-Graduação em Direito, Belém-PA, Brasil.
} iD https://orcid.org/0000-0002-0486-2973

\begin{abstract}
Resumo: Em um momento sociopolítico muito apropriado, de redefinição da noção prática de representação e soberania popular, reflete-se a respeito da participação da sociedade nas políticas públicas urbanísticas como exercício da referida soberania. Como arena inovadora ou canal de envolvimento da população em geral nas decisões políticas, em vários âmbitos da atuação governamental, a mencionada participação corresponde, na prática, a um mecanismo que serve apenas para validar e legitimar os interesses políticos e econômicos que proliferam nos patamares públicos e privados, inclusive, nos setores hegemônicos, em particular no mercado. Utiliza-se a abordagem qualitativa, a analise bibliográfica e documental, principalmente a ADI $\mathrm{n}^{\circ}$ 0303489-40.2012.8.05.0000, julgada, no início de 2014, pelo TJ/BA, que decidiu pela inconstitucionalidade parcial e geral de leis do município de Salvador cujo Plano Diretor alteraram, sem garantir ampla e efetiva participação popular. Parte-se da hipótese de que essa participação, decorrente e expressão direta da soberania popular, não se configura automaticamente em arena política apta para oportunizar e consolidar práticas democráticas de gestão pública. A soberania popular funciona como subterfúgio ideológico ou mecanismo artificial que escamoteia a verdadeira face da dominação neoliberal-capitalista traduzida na atuação estatal, que, via de regra, está permeada pelos interesses de setores privados.
\end{abstract}

Palavras-chave: Racionalidade neoliberal. Políticas públicas urbanísticas.

Participação. Soberania popular.

* Doutorando em Direito pela UFPA. Professor de História na SEDUC. Bolsista da Coordenação de Aperfeiçoamento de Pessoal de Nível Superior (CAPES). E-mail: dnnonato@yahoo.com.br

** Doutor em Direito pela UFPA. E-mail: rwraiol@gmail.com

*** Mestrando em Direito pela UFPA. E-mail: romariorebelo@live.com

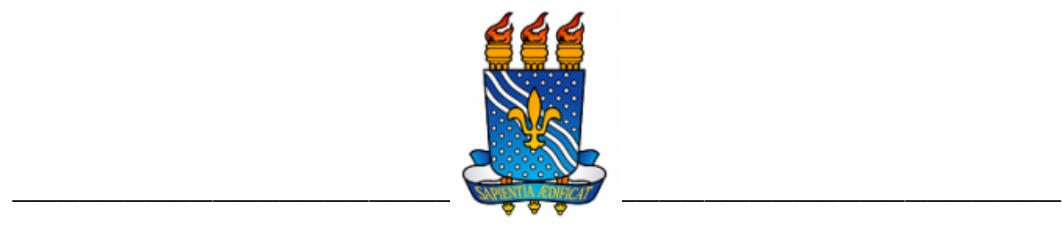

UNIVERSIDADE FEDERAL DA PARAÍBA

Programa de Pós-Graduação em Ciências Jurídicas

DOI: https://doi.org/10.22478/ufpb.1678-2593.2021v20n44.38373 


\title{
Racionalidade Neoliberal E Política Pública Urbanística Frente Ao Direito De Participação Popular: Uma Análise Da ADI 0303489-40.2012.8.05.0000
}

\section{Domingos do Nascimento Nonato}

\author{
Raimundo Wilson Gama Raiol
}

Romário Edson da Silva Rebelo

\section{INTRODUÇÃO}

O direito à participação popular nas políticas públicas urbanísticas é de suma relevância. Impõe-se, assim, ser analisado. Trata-se de manifestação direta da soberania popular. É grande sua importância diante de sua vinculação à gestão pública, especialmente abrangendo a elaboração, execução e fiscalização do cumprimento dos instrumentos ou ferramentas da política urbana previstas no Estatuto da Cidade.

Visando a isso, faz-se, na fluência deste artigo, a análise desse instrumento de política urbana e sua decorrência da soberania popular, em harmonia com os meandros da Constituição da República, sob a saudação de Constituição Cidadã, como vanguardeira do Estado Democrático de Direito, um dos seus pilares.

Com efeito, estudar-se-ão a participação popular e a soberania popular, buscando-se evidenciar elementos de interligação entre ambas. Ao lado disso, serão levadas em consideração a existência de relação da predita participação com a lógica do capitalismo neoliberal 
e, também, os reflexos sofridos pela participação popular ante a modificação legislativa que a minimizou no bojo das Leis Municipais $\mathrm{n}^{0}$ s. 8.167/2012, 8.378/2012 e 8.379/2012, que alteraram o Plano Diretor do Município de Salvador, capital do Estado da Bahia. Essa alteração, feita unilateralmente pelo legislador municipal, implicou em deixar de garantir a efetiva participação popular acerca de questões atinentes à política urbana, em ofensa à Constituição daquela Unidade Federativa.

Tendo como fulcro a Ação Direta de Inconstitucionalidade (ADI no 0303489-40.2012.8.05.0000), proposta pelo Ministério Público do Estado da Bahia, em desfavor da Câmara de Vereadores e do Município de Salvador, e julgada, em 2014, pelo Tribunal de Justiça daquela Unidade da Federação, haverá abordagem no que tange ao entendimento da predita Corte no sentido de que se afigura inconstitucional norma municipal alteradora do Plano Diretor, sem a efetiva participação comunitária no processo de modificação desse diploma legal, como se verificou, in casu, por imposição daquelas 3 (três) leis municipais.

Mais adiante, ocorrerá a discussão em torno da participação popular e da democracia representativa, partindo do conceito de política pública, o que se aprofunda levando em conta a articulação entre esta e aquelas, para atender aos interesses sociais. Nessa trilha, anota-se que o aparato normativo da participação popular não impede a lógica mercadológica, que guia a atuação do Poder Público em relação aos espaços urbanos, nem a superficialidade na utilização da referida participação; em suma, como resulta da análise da precitada ADI, cogita-se acerca da substituição do planejamento urbano pela imposição de satisfazer a interesses voltados para a referida lógica, sobretudo, os de natureza imobiliária e de (re)produção e utilização do espaço urbano. Por força disso, a participação popular se reduziu a mera figura de retórica, que atomiza a representação do interesse público em atendimento à lógica do neoliberalismo. 
Desse modo, a temática a ser desenvolvida, ao longo deste texto, tem como base a problematização que se sintetiza na seguinte indagação: Há uso efetivo da participação popular como instrumento de política pública de urbanização? O objetivo norteador da explanação relativa à temática é o de refletir quanto à significação e importância do instituto da participação popular, questionando se sua efetividade se presta para legitimar os interesses político-econômicos da gestão pública e do mercado, que representam a lógica do neoliberalismo.

$\mathrm{O}$ artigo é fruto de pesquisa qualitativa, bibliográfica e documental, no que se insere a ADI mencionada, aresto que será objeto do método de análise de jurisprudência, que consiste em coletar uma decisão acerca de um problema jurídico e permite identificar um momento decisório, as posições dos julgadores e as eventuais inclinações para as demais possibilidades de solução da lide ou demanda ajuizada, como se pode interpretar dos ensinamentos de Freitas Filho e Lima (2010, p. 2 e 3), a qual, no caso, abarca a problematização acima caracterizada.

\section{SACRALIZAÇÃO JURÍDICO-POLÍTICO DA SOBERANIA POPULAR}

A Constituição da República de 1988, que tornou o Brasil um Estado Democrático de Direito, representa um marco para a política nacional, tendo a soberania popular como uma das linhas-mestras dessa mudança jurídico-institucional, porque, no art. $1^{0}$, parágrafo único, a Carta Política consagra juridicamente a dita soberania popular, ao declarar: "Todo o poder emana do povo, que o exerce por meio de representantes eleitos ou diretamente, nos termos desta Constituição."

Em razão disso, quem detém o poder político é o povo, que se encontra revestido de autoridade suprema. Logo, nos expressos 
termos da Constituição da República, a soberania política pertence ao povo, a ninguém mais. Na acepção jurídica, a mencionada soberania prevê que os indivíduos sejam seus autores e destinatários, ao mesmo tempo. Como regra, porém, esse poder é exercido por seus representantes eleitos por meio do voto (via indireta).

Há, ainda, o exercício direto desse poder pelo povo, chamado de democracia direta, nos termos que prescreve o texto constitucional, no art. 14, do Capítulo reservado aos Direitos Políticos: “A soberania popular será exercida pelo sufrágio universal e pelo voto direto e secreto, com valor igual para todos, e, nos termos da lei, mediante: Iplebiscito; II- referendo; III- iniciativa popular”.

Essas normas constitucionais correspondem ao que se entende como Espírito da Constituição, o principal ethos da democracia, uma verdadeira sacralização jurídico-política da soberania popular, traçado no Preâmbulo, ao declarar que os representantes do povo brasileiro se reuniram em Assembleia Nacional Constituinte para a instituição de Estado Democrático.

Como desdobramento da soberania popular, a participação popular tem sido reafirmada no Brasil, ao argumento de que posiciona a população como colaboradora e corresponsável das instituições e atos ou ações dos poderes públicos, dessa forma, estreitando as relações entre Estado e sociedade, ampliando a cidadania ao estabelecer inúmeros arranjos institucionais, colimando promover a abertura desse Estado à efetiva participação do povo em sua gestão e controle. Por essa lógica, se o povo é o titular legítimo do poder estatal, cujo exercício pode ser direto ou por meio de representantes livremente eleitos, a participação popular tem, pois, papel relevante tanto no que concerne à expressão de demandas como em relação à democratização da gestão e da execução das políticas públicas.

A participação popular direta não deixa de representar um ganho significativo para a sociedade e a democratização do poder político, pois, afinal, segundo preleciona Nunes (2006, p. 14), “num país onde o poder de decisão foi historicamente monopolizado pelos 
representantes de uma elite econômica muito restrita, a participação da população significa uma democratização desse poder". Demarcando novas institucionalidades para a democracia brasileira, os instrumentos do texto constitucional preveem a participação de maneira mais direta da sociedade em geral nas decisões políticas, em inúmeros campos de atuação governamental, que se fez "acompanhada da consolidação de uma nova institucionalidade objetivando assegurar a presença de múltiplos atores sociais, seja na formulação, na gestão, na implementação ou no controle das políticas sociais", como lembram Silva, Jaccound e Beghin (2005, p. 375).

Vê-se, desse modo, que a participação popular está justamente no centro dos problemas ligados a essa nova institucionalidade política, porque, no mundo contemporâneo, altamente complexo, a lógica estruturante dos mecanismos de atuação do capitalismo neoliberal trabalha pela negação, encolhimento ou redução do político à política dita democrática, lógica está vinculada a um amplo processo de redução do Estado e à valorização da incorporação de atores externos ao processo político e à gestão de políticas públicas.

À luz dessa nova institucionalidade da democracia brasileira, reflete-se, ao longo deste estudo, a respeito da participação popular, no que se designa de políticas públicas, como um exercício da soberania consagrada no Estado Democrático de Direito do Brasil, indagando se, apesar de apresentada como arena política inovadora ou canal de envolvimento da população em geral nas decisões políticas, em vários âmbitos da atuação governamental, a referida participação corresponde, na prática, a um mecanismo reservado apenas para legitimar os interesses políticos e econômicos dos gestores públicos e do mercado.

Nesse contexto, é relevante mencionar, assim, a valiosa análise que Teixeira e Albuquerque (2018, p. 13) fazem relativamente aos interesses mercadológicos do capitalismo neoliberal que colonizam a possibilidade de participação popular frente ao Poder Público e às situações pertinentes à coletividade. 
Ora, os modernos Estados Democráticos de Direito devem se fundar tanto na liberdade política quanto na igualdade de participação dos cidadãos perante o poder e as questões afetas à sociedade, o que, infelizmente, não ocorre devido a colonização dos mecanismos políticos, jurídicos e culturais pela plutocracia hegemônica.

Os autores deixam transparecer que não basta o Estado Democrático de Direito proclamar a liberdade política e a igualdade de participação dos cidadãos, na busca de resolução dos problemas da sociedade, pois isso encontra óbice na colonização de diversos mecanismos, dentre os quais os políticos, jurídicos e culturais. Diante desse quadro, vislumbra-se as dificuldades enfrentadas pelos membros da sociedade para que tenha efetivado o seu direito de representação, o que se refletiu no processo legislativo que resultou na alteração do plano diretor cuja análise é colimada, ao longo deste estudo.

Tudo isso considerado e tomando como norte a Ação Direta de Inconstitucionalidade - ADI - $\mathrm{n}^{\mathrm{o}}$ 0303489-40.2012.8.05.0000, julgada no início de 2014, pelo Tribunal de Justiça do Estado de Bahia, que decidiu pela inconstitucionalidade parcial e geral das leis que alteraram radicalmente o Plano Diretor do município de Salvador, sem garantir a ampla e efetiva participação popular, o fio condutor deste estudo é indagar criticamente a respeito da concepção de soberania popular inaugurada com a modernidade capitalista e como ela se espraia nas democracias liberais contemporâneas, como a brasileira.

Parte-se da hipótese de que a participação popular como decorrência e expressão direta da soberania popular não se configura automaticamente em arena política apta para oportunizar e consolidar práticas democráticas da gestão pública. Evidências empíricas extraídas do caso em epígrafe permitiram constatar a superficialidade por parte dos habitantes de Salvador no que concerne ao exercício do direito à participação popular, que, sob o selo democrático, serviu mais para a validação e legitimação de mecanismos e decisões definidas por setores hegemônicos, cujos interesses são sempre atendidos. A soberania popular funciona como subterfúgio ideológico ou mecanismo artificial que escamoteia a verdadeira face da dominação 
neoliberal-capitalista traduzida na atuação estatal, que, via de regra, está permeada pelos interesses de setores privados.

A Constituição Federal de 1988 destinou um capítulo específico para tratar da Política Urbana, todavia, para que os princípios, diretrizes e instrumentos então enunciados no texto constitucional ganhassem densificação normativa e tendessem à implementação da referida política, era necessária uma legislação específica de abrangência nacional. Nesse sentido, após um longo período de negociações, em 10 de julho de 2001, foi finalmente aprovada a Lei Federal $n^{0}$ 10.257, conhecida como Estatuto da Cidade, que regulamentou os artigos 182 e 183 da Constituição da República, normas estas relativas à política urbana.

Se o Capítulo IV do Estatuto da Cidade, dedicado à gestão democrática, visa, permitir a participação popular em todas as etapas ou dimensões do planejamento, implementação e avaliação de políticas públicas urbanísticas, a realidade tem demonstrado que a esfera local, que seria mais propícia à mobilização da população e ao envolvimento desta na resolução de problemas de interesse público, quando a dita participação dos munícipes acontece, acaba, invariavelmente, atuando para conferir legitimidade às ações governamentais, ao invés de exercer o controle dessas mesmas ações, muitas das quais a favor da lógica capitalista de (re)produção e apropriação privada do espaço urbano, mercantilizando as decisões e transformando, assim, essa participação em instrumento a serviço do capital.

\section{GÊNESE DA SOBERANIA POPULAR: A LÓGICA PERVERSA DA MODERNIDADE CAPITALISTA}

Apesar de algumas variantes referentes à gênese da chamada modernidade, é indubitável a sua relação com o surgimento do capitalismo, como lembra Giddens (1991. p. 20): "A ordem social emergente da modernidade é capitalista tanto em seu sistema 
econômico como em suas outras instituições”. Nessa vertente, o que não se pode perder de vista, na abordagem dessa relação, é que, a despeito da sua atualidade, suas raízes têm como marco as tradições políticas da modernidade que emergiram desde o século $\mathrm{XV}$, sendo essencial, assim, retornar às suas matrizes para compreender como e porque a soberania popular, como fonte e protótipo do poder político, foi forjada no contexto de emergência da racionalidade moderna capitalista, racionalidade instrumentalizada, por conseguinte, de natureza eminentemente prática, posta em função da dominação e da hegemonia política e econômica que passa a vigorar nas sociedades.

$\mathrm{Na}$ transição do sistema feudal para a ordem capitalista, no plano formal, emergiram direitos relacionados à liberdade e à igualdade. A propósito, Wood (2003, p. 182) expende seus comentários sobre essa transição: "Evidentemente, a dissolução de identidades normativas tradicionais e de desigualdades jurídicas representou um avanço para esses indivíduos 'livres e iguais'; e a aquisição da cidadania conferiu a eles novos poderes, direitos e privilégios”. Paradoxalmente, todavia, continua Wood (2003, p. 182183), salientando que não se pode medir os ganhos e perdas da soberania popular, sem lembrar que a cidadania, devido à desvalorização que lhe adveio na esfera política, devido à nova relação entre "econômico" e "político", sofreu redução de importância e transferiu alguns de seus poderes exclusivos para o domínio totalmente econômico da propriedade privada e do mercado.

Sabe-se que, via de regra, nas democracias liberais contemporâneas, vigora a concepção da soberania popular, isso porque o povo, que se encontra revestido de autoridade suprema, é o titular legítimo do poder estatal, cujo exercício pode ser direto ou por meio de representantes livremente eleitos. Por essa lógica, do ponto de vista formal, nos ditos Estados Democráticos de Direito, aí incluída a maioria das repúblicas, como a brasileira, os Estados são criados e estão sujeitos à vontade das pessoas, que são a fonte de todo o poder político. Essa compreensão política da modernidade capitalista está 
intimamente associada aos filósofos contratualistas, dentre eles Thomas Hobbes e John Locke.

A visão contratualista de Hobbes está expressa na obra Leviatã, cujo tema central é o homem e sua natureza, nesta inserido, um ser que, devido à sua natural condição, está em constante ou permanente estado de guerra contra seus iguais. $\mathrm{O}$ homem é assim um lobo para o homem, pois, na condição de igualdade com seu semelhante, pode querer a mesma coisa ao mesmo tempo que outro e, dessa feita, ficam inimigos entre si. Naturalmente agressivo e egoísta, acima de tudo, só pensando na autopreservação, na sua liberdade ilimitada, o homem impede que haja qualquer progresso social, em decorrência de viver em uma guerra de todos contra todos, em disputa generalizada e constante (HOBBES, 1998).

Diante desse quadro caótico, o encaminhamento apontado por Hobbes para garantir a paz comum é o dos homens estabelecerem um acordo entre si, o qual consiste na renúncia à liberdade natural de fazer tudo sem limites em favor de um terceiro, a quem cabe impor limites comuns e adequados, mediante leis morais e políticas, para todos os homens que aceitaram o pacto. $\mathrm{O}$ homem que estabelece as leis para os outros é o soberano e cabe a ele governar a sociedade assim formada. Hobbes acredita no contrato social como fundador, simultaneamente, da sociedade e do Estado, composto por regras de convívio e de subordinação política (HOBBES, 1998).

Além de oferecer base político-filosófica bastante sólida para as monarquias absolutistas em ascensão, nesse período, na Europa, Hobbes encontra também uma definição para a soberania e para a representação política, além de inaugurar, ademais, a separação metafísica entre a liberdade e a racionalidade. A hipótese de Hobbes caminha no sentido de pensar o poder como resultado de um acordo, de um pacto, ou seja, o poder é consentido por aqueles que se submetem, o que enseja ao soberano fazer uso da força e da violência como instrumentos ou estratégias para o garantir (HOBBES, 1998).

Hobbes inaugura a tradição contratualista fundada no artifício filosófico "Estado de Natureza - Contrato - Estado Político", esquema 
fictício que explica a noção de soberania do Estado moderno, originário e que repousa na ideia de sociedade organizada por uma pessoa abstrata (Leviatã), a qual é materializada por um governo constituído ou por um homem (em uma monarquia) ou por uma assembleia de homens (uma aristocracia ou uma democracia). $\mathrm{Na}$ prática, na época da organização das monarquias absolutistas, os súditos entregam ao monarca (soberano) suas liberdades irrestritas de quererem tudo em troca da segurança e da paz, proporcionadas pelo contrato racionalmente estabelecido. Logo, o soberano exerce o poder político em nome de todos os homens (os súditos), porque estes, em um ato de extrema liberdade, sendo, de tal modo, irreversível, assim decidiram. O poder absoluto do soberano está fundado, em virtude disso, na representação que ele exerce perante e sobre seus súditos, sem qualquer exceção. Todos os seus atos são, pelo princípio da representação, atos de seus próprios súditos. Em uma explicação tautológica: a vontade do soberano é a vontade de todos os súditos e todos os súditos têm suas vontades expressas pela voz e pelas leis do soberano. Em sendo atos tomados pelo soberano, em nome de seus súditos, esses são, consequentemente, atos dos próprios governados, em nome de seus próprios interesses (HOBBES, 1998).

Locke (1983), por seu turno, mostrou que as ideias inatas são oriundas dos sentidos, das sensações humanas, sendo o homem uma tabula rasa a ser preenchida ao longo de sua vida. Aqui reside a sacada política de Locke: como é a partir do corpo (dos sentidos) que o homem sente, então o homem percebe ou adquire uma noção de propriedade, vez que é dono do próprio corpo. A mesma lógica é aplicável quanto aos bens que produz, pois é dono daquilo que produz com seu próprio corpo enquanto instrumento de sua liberdade.

Não por outra razão, predomina na literatura crítica uma interpretação que apresenta a filosofia política de Locke como justificativa ideológica do individualismo possessivo, com destaque para a análise de Macpherson (1962), sociólogo canadense, desenvolvida na Teoria política do individualismo possessivo, cuja 
ênfase cai na teoria da propriedade e que apresenta Locke como um dos teóricos que justificam um certo tipo de individualismo/utilitarismo do homos economicus. Na qualidade de crítico da democracia liberal e incentivador da democracia participativa, Macpherson (1962), de modo particular, analisou obras de Locke (Primeiro e Segundo Tratados sobre o Governo), chegando à conclusão de que esse autor estaria justificando a propriedade privada individual e a legitimidade da apropriação e acumulação de bens sem limites, no contexto de uma sociedade capitalista, logo, validando e legalizando os interesses, valores e ideais dos burgueses de então.

Segundo Locke (1983), se o homem pode produzir o que precisa, então não há por que brigar com outros homens; diferentemente de Hobbes, concluiu que a natureza humana é pacífica. Eventualmente, porém, surgem conflitos, riscos e casos de instabilidades. Nessas situações, vence o mais forte, não o mais justo, daí a necessidade de o homem formar a sociedade política mediante um contrato, um pacto social, com base no qual, ao contrário de ser vencedor o mais forte, em detrimento do mais justo, os homens renunciam ao direito de defesa e de fazer justiça, para esta se sobrepor à injustiça. Como consequência, decorre o imperativo sociopolítico de constituir o Estado para regular conflitos, equilibrar as forças e proteger a vida, a liberdade e os bens ou propriedades individuais (MACPHERSON, 1962).

A filosofia política de Locke, como justificativa ideológica do individualismo possessivo, defensora da nova forma de vida social individualista e capitalista que estava nascendo naquele período, sustenta uma concepção de sociedade política bem ordenada que, por intermédio de vínculo comum (pacto social), resulte em um governo legítimo (soberano) que se apoie na conciliação entre os direitos individuais fundamentais e a soberania popular, tendo em vista o bem comum de uma comunidade de indivíduos livres e iguais que cooperam entre si, donde a origem do governo está justamente no consentimento da soberania popular. Cada indivíduo tem o direito de 
resistir ao governo, quando este não respeita aquele objetivo (MACPHERSON, 1962).

Abre-se um parêntese para sublinhar que Foucault (2005), ao apontar algumas precauções metodológicas para decifrar ou tornar inteligível as relações de poder de modo ascendente, critica o esquema hobbesiano de formação de um corpo social, cujos indivíduos estão interligados por uma alma que seria a soberania. Nessa seara, eis a manifestação de Foucault (2005, p. 34):

[...] o Leviatã, enquanto homem fabricado, não é mais do que a coagulação de um certo número de individualidades separadas, que se encontram reunidas por certo número de elementos constitutivos do Estado. Mas, no coração, ou melhor, na cabeça do Estado, existe uma coisa que o constitui como tal, e essa alguma coisa é soberania, da qual Hobbes diz que é precisamente a alma do Leviatã. [...].

Nas raias desse pensamento crítico à teoria de Hobbes, que entende ser a soberania a alma do Leviatã, por esse viés, acompanhando a manifestação de Foucault no sentido de que na cabeça do Estado está a soberania, a que correlacionada a participação popular, há que se compreender que essa intervenção da população de um município deve ser respeitada quanto à elaboração ou alteração de leis concernentes aos seus mais comezinhos interesses, como os previstos no plano diretor municipal, disso decorrente a inconveniência político-administrativa e a ausência de legitimidade de atitudes do legislador que, olvidando da referida participação, altera o teor normativo de predito instrumento de política urbana.

Depreende-se que a preocupação de Foucault com a questão metodológica caminha no sentido de estudar os operadores materiais que produzem técnicas e táticas de dominação, de sujeição de indivíduos reais pelo Estado. Nas palavras de Foucault (2005, p. 40):

[...] é preciso desvencilhar-se do modelo do Leviatã, desse modelo de um homem artificial, a um só tempo autômato, fabricado e unitário igualmente, que envolveria todos os indivíduos reais, e cujo corpo seriam os cidadãos, mas cuja alma seria a soberania. É preciso estudar o poder fora do modelo do Leviatã, fora do campo delimitado pela soberania jurídica e pela instituição do Estado; trata-se de analisá-la a partir das técnicas e táticas de dominação. [...]. 
Sob o influxo dessa crítica de Foucault à teoria de Hobbes, ou seja, manifestação do filósofo francês que sugere certo resíduo autoritário e unilateral do Leviatã, como se pode depreender, e procura desse modelo liberar o poder, para que a soberania seja analisada, considerando técnicas e táticas de dominação, vislumbra-se como desdobramento desta a participação popular, a servir de respaldo à intervenção no processo de elaboração e alteração de diplomas legais no pertinente a seus interesses ou direitos, decorrendo dessa concepção que foi ilegal e ilegítima a edição das leis alteradoras do Plano Diretor do Município de Salvador, capital baiana.

Se, remontando ao século XVI, a teoria jurídico-política da soberania desempenhou vários papeis, dentre os quais ter servido de justificação para a formação das monarquias europeias naquele período, no século XVIII, também foi utilizada para explicar um modelo alternativo, o das democracias parlamentares, às monarquias autoritárias e absolutas que vigoravam até então.

Em uma guinada epistemológica, Bourdieu (2011, p. 95-96) se esforça intelectualmente para explicar o modelo de emergência do Estado moderno. Nessa empreitada, adverte no tangente às potencialidades e dificuldades metodológicas relativas aos estudos iniciais levados a efeito por intelectuais dos séculos XVI e XVII:

A dificuldade específica da questão do Estado prende-se ao fato de que, sob a aparência de pensá-lo, a maior parte dos estudos consagrados a esse objeto, sobretudo em sua fase de construção e consolidação, participam, de modo mais ou menos eficaz e mais ou menos direto, de sua construção, logo, de sua própria existência. É esse, particularmente, o caso de todos os estudos dos juristas dos séculos XVI e XVII, que só fazem sentido se sabemos ver neles não contribuições meio atemporais à filosofia do Estado ou descrições quase sociológicas, mas programas de ação política que pretendem impor uma visão particular do Estado, de acordo com os interesses e os valores associados à oposição ocupada por aqueles que os produzem no universo burocrático em vias de constituição $[\ldots]$.

Depreende-se dessas asserções de Bourdieu que os estudos acerca do Estado só fazem sentido se revelarem ação política 
relacionada "aos interesses e valores associados à oposição por aqueles que os produzem no universo burocrático em vias de constituição". Trazendo para o âmbito da explanação que ora faz, isso significa que se justifica a ação política pautada na representação popular na formulação de leis, em contraponto ou oposição à burocracia que as altera olvidando daquela representação, que deveria ser prezada e ouvida para a legitimidade das iniciativas do legislador, o que, in casu, se aplica na demonstração de que a referida representação deveria ter sido oportunizada na tarefa de alteração do plano diretor da capital baiana.

Se, por um lado, Bourdieu critica o viés metodológico clássico utilizado por Max Weber para definir o Estado, por outro, também desenvolve um pensamento crítico referente ao Estado. Os pensadores do início da modernidade, principalmente juristas, se encarregaram de formular as bases das teorias políticas dos Estados modernos em ascensão. Como visto antes, Hobbes, por exemplo, formula a ideia do soberano, "pessoa artificial", que representa os súditos, de modo que essa ficção teológica associa o Estado a uma pessoa coletiva, personificando um ente inanimado. Se o Estado representa essa coletividade política instituída mediante pacto social, os súditos devem aceitar sua autoridade como natural, evidente e manifesta.

Colocando em questão os pressupostos do "conformismo lógico" e do "conformismo moral" inscritos nas experiências sociais, Bourdieu (2011, p. 98) sugere o que denomina de modelo da emergência do Estado, para compreender criticamente o Estado, ou seja, "visando dar conta, de modo sistemático, da lógica propriamente histórica dos processos ao termo dos quais se instituiu isso que chamamos de Estado", na expressão literal de Bourdieu (2011, p. 98). Para além da concentração de um capital de força física, como privilegiam os modelos explicativos formulados pelos marxistas clássicos e por Max Weber, Norbert Elias e Charles Tilly, Bourdieu (2011, p. 99) descreve o Estado moderno como "resultado de um processo de concentração de diferentes tipos de capital, capital de 
força física ou de instrumentos de coerção", acrescentando que essa concentração "constituiu o Estado como detentor de uma espécie de metacapital, com poder sobre os outros tipos de capital e sobre seus detentores", discernindo o autor como diferentes tipos de capital os seguintes: "capital econômico, capital cultural, ou melhor, de informação, capital simbólico".

Bourdieu (2011, p. 99-100) salienta que "a construção do Estado está em pé de igualdade com a construção do campo do poder" e que, nesse espaço, "os detentores de capital (de diferentes tipos) lutam particularmente pelo poder sobre o Estado, isso é, sobre o capital estatal que assegura o poder sobre os diferentes tipos de capital e sobre sua reprodução".

Denota-se, com fulcro nesse cotejo feito por Bourdieu, que há um campo de forças dentro da estrutura do Estado. Filtra-se desse campo a existência de capital representativo da soberania popular, que, no jogo de forças, exerce sua influência sobre o próprio Estado, contribuindo para este e devendo por este ser direcionada em favor da sociedade

Com plena razão, conseguintemente, no aludido jogo de forças, a soberania popular deve ser respeitada na conjuntura de uma formulação de leis, mediante apreço à representação popular, o que não deveria ter sido olvidado para a feitura das normas jurídicas que alteraram o plano diretor alvo de comento.

\section{O QUE A JURISPRUDÊNCIA REVELA SOBRE A PARTICIPAÇÃO POPULAR: O CASO DA ADI No o303489- 40.2012.8.05.0000}

A jurisprudência brasileira, no que se refere ao controle social das políticas públicas, consolida-se mais em relação aos direitos à saúde e à educação, sendo bastante tímida no que concerne aos direitos sociais urbanísticos, como moradia, infraestrutura, 
saneamento, mobilidade etc., inclusive, comumente, atribui-se ao Poder Judiciário um caráter conservador e desconhecedor das questões e problemáticas urbanas.

É inegável a missão constitucional do Poder Judiciário para a implementação de normas estabelecidas e não cumpridas pelo Poder Executivo. A contemporaneidade reclama a atuação relevante do Poder Jurisdicional frente ao clamor pela efetiva soberania popular, mediante uma democracia participativa que propicie a garantia ao titular do direito àquilo que está afirmado no direito material. A intercessão do Poder que maximiza a função de julgar do Estado é viável frente ao outro Poder, para que dê cumprimento às referidas normas, consoante a ilação que permite o que declaram Mariotti, Fernandes e Lunelli (2018, p. 7):

A afirmação de que é possível - e devido - o controle dos atos da administração pública, pelo judiciário, também implica na admissibilidade da atuação do Poder Judiciário no momento em que o poder executivo não realiza as diretrizes estabelecidas no ordenamento constitucional.

Pelo que se deduz, ante isso, havendo viabilidade de controle pelo Poder Julgador em relação aos atos inerentes à administração pública, a falta de acuidade ou não execução para que se realizem adequadamente e em simetria com os parâmetros constitucionais pode ser solucionada mediante julgamento que, sem ferir a independência dos Poderes, em um Estado uno, determine que os preditos atos se materializem, inclusive, em sede de política urbana, em nome da soberania popular. No caso em análise, as leis modificadoras do Plano de Direitos, por terem olvidado a participação popular no processo legislativo, estão inquinadas de vícios que não podem fugir à senda avaliativa do Poder Jurisdicional, em obediência ao princípio esculpido no art. $5^{\circ}, \mathrm{XXXV}$, da vigente Constituição da República, o qual preceitua que "a lei não excluirá da apreciação do Poder Judiciário lesão ou ameaça a direito". Desse modo, o controle judicial das políticas públicas urbanas é um desafio para o Poder Judiciário, que está legitimado a intervir para a implementação dos 
deveres fundamentais urbanísticos atribuídos, na Carta da República e nas leis esparsas, ao Executivo, impondo-lhes sanções.

Por outro lado, com relação ao Poder Legislativo, a intervenção é realizada por meio de controle de constitucionalidade de normas, como aconteceu no tocante à Ação Direta de Inconstitucionalidade (ADI $\mathrm{n}^{0}$ 0303489-40.2012.8.05.0000), julgada, no início de 2014, pelo Tribunal Pleno do Tribunal de Justiça do Estado da Bahia, que, por maioria absoluta de votos, declarou a inconstitucionalidade de alguns dispositivos da Lei Municipal $\mathrm{n}^{\mathrm{o}}$ 8.167/2012 ${ }^{1}$, bem assim no que tange à integralidade das Leis $\mathrm{n}^{\mathrm{O}} \mathrm{S}$ 8.378/12 e 8.379/2012 (TJ/BA, 2014, p. 1 e 3), que alteraram radicalmente o Plano Diretor do município de Salvador, sem garantir a ampla e efetiva participação popular, contrariando, assim, a democracia participativa.

Em breve inserção, vale frisar a relevância da participação do Poder Judiciário para o desate de demandas para solução de conflitos de interesses. Nesse passo, oportuna é a alocução de Mariotti, Fernandes e Lunelli (2018, p. 17), nos seguintes moldes: “ O acesso à justiça, portanto, é componente imprescindível para a concretização da participação popular, relevando-se como uma das facetas da democracia participativa insculpida na Constituição Federal". Convém acrescentar: "Para que haja uma participação popular fundada na Constituição passa-se necessariamente por um Judiciário cônscio de seu novo papel na prestação de uma jurisdição que possa efetivar a participação da coletividade”. (MARIOTTI, FERNANDES e LUNELLI, 2028, p. 23). Essas premissas são constatáveis, na incursão que se faz em atinência ao julgado resultante no bojo da supracitada ADI, no qual prevaleceu o comando para a efetividade da representação popular.

\footnotetext{
${ }^{1} \mathrm{O}$ prefeito de Salvador, sob a alegação de preparar a cidade para receber os investimentos da Copa do Mundo, enviou à Câmara de Vereadores um projeto de Lei, conhecido como PPDU da Copa sem que houvesse participação ou controle social. Por meio desse Projeto de Lei foi proposta uma mudança substancial no Plano Diretor, culminando na promulgação da Lei 8.167/2012. Em apertada síntese, a proposta tinha como foco uma ampla alteração na estrutura urbanísticas e de zoneamento, visando possibilitar a verticalização, adensamento e mudança de uso em diversas áreas da cidade. Também apresentava mudança no traço viário e sistema de mobilidade urbana.
} 
A escolha desse caso baiano reveste-se de singular importância, porque, além de ser um julgamento que delineia os traços mais relevantes do entendimento ou interpretação do Poder Judiciário no tocante a aspectos ou temáticas relacionadas à designada democracia urbana, sendo, à vista disso, um exemplo típico da postura política desse Poder frente a esse caso, mostra, de maneira bastante explicita, a "nova arte de governar", como refere Foucault (2008), que nega a soberania popular, pelo menos, na forma como ocorre na contemporaneidade, fundamentada apologeticamente na democracia. Desse modo, apesar de se apresentar, em tese, como arena política inovadora ou canal de envolvimento da população em geral com as decisões políticas, em vários âmbitos da atuação governamental, a participação popular corresponde, na prática, a um mecanismo que serve apenas para validar e legitimar interesses escusos de gestores públicos e de setores hegemônicos, em particular do mercado.

A mencionada ADI foi proposta pela Procuradoria Geral de Justiça, do Ministério Público do Estado da Bahia², em face da Câmara de Vereadores e do Município de Salvador, mediante a qual se impugnava leis municipais que alteraram radicalmente o Plano Diretor, sem garantir a ampla e efetiva participação popular, por esse motivo, uma ofensa à Constituição3 ${ }^{3}$ do Estado da Bahia. Como as leis impugnadas teriam alterado substancialmente o Plano Diretor de Desenvolvimento Urbano de Salvador (PDDU), sem oportunizar o necessário debate com a comunidade, o órgão ministerial arguiu que

${ }^{2}$ Frisa-se que o Ministério Público agiu em decorrência de representação encaminhada por inúmeros movimentos sociais pretendendo anular o novo Plano Diretor de Salvador. A partir dessa representação, o órgão ministerial baiano ajuizou ADIn com suporte na Lei 8.167/2012, alegando que a ausência de participação popular no processo de reformulação do dito Plano Diretor, contrariava o princípio da democracia participativa, na medida em que não oportunizou o necessário debate com a sociedade, violando, assim, a Constituição do Estado da Bahia.

3 O órgão ministerial, autor da ação, afirmava que as leis impugnadas padeciam de inconstitucionalidade, por evidente violação à Constituição do Estado da Bahia, essencialmente, aos arts. 60 e 64, incisos IV e V, em razão de afronta ao devido processo legal legislativo, e aos arts. 167, 168 e 225 do mesmo diploma, por desrespeito às exigências mínimas de fundamentação de normas do ordenamento do uso do solo urbano em estudos prévios de sustentabilidade ambiental e concordância com o Plano Diretor, bem como abuso do poder de emenda e invasão de competência privativa. 
tais normas eram inconstitucionais, por vício no processo legislativo, vez que não foi garantida também a participação popular nos processos de elaboração das ditas leis, contrariando, assim, o princípio da democracia participativa.

No relato dos fatos, o Tribunal esclareceu que o órgão ministerial alegou, dentre outros pontos, a existência de ofensa ao devido processo legislativo especial previsto para elaboração e alteração do PDDU, ante o descumprimento de exigências básicas, tais como "a promoção de audiências públicas e debates com a participação da população e de associações representativas dos vários segmentos da comunidade, a publicidade e o acesso aos documentos e informações produzidos.” (TJ/BA, 2014, p. 5).

Dentre os argumentos utilizados, o Município de Salvador, “alegou a impossibilidade jurídica do pedido, pois a Constituição baiana apenas traz regras específicas para a elaboração ou alteração do PDDU, e a norma impugnada seria mera lei ordinária.” (p. 5-6). Por seu turno entre as justificativas usadas, a Câmara de Vereadores também "alegou que foram realizadas audiências públicas para discussão do Projeto de Lei, inclusive em localidades distintas." (TJ/BA, 2014, p. 6).

Chamou atenção o fato da Associação de Dirigentes de Empresas do Mercado Imobiliário da Bahia - ADEMI-BA ter formulado pedido de intervenção no feito, na condição de amicus curiae $^{4}$, o que foi deferido. Em seu pronunciamento, a dita Associação

4 A expressão latina amicus curiae significa, literalmente, "amigo da corte" ou do tribunal. É a figura interventiva, dotada de personalidade natural ou jurídica, que atua como representatividade adequada, colaborando em processos judiciais em matéria de significativa relevância. Nesse sentido, Didier Junior (2010, p. 404) afirma que a figura do amicus curiae (amigo da corte) é uma forma de intervenção, a fim de auxiliar o juízo, provocada pelo magistrado ou pelo próprio amicus curiae. Seu principal objetivo consiste em aprimorar as decisões do Poder Judiciário, dando um apoio técnico ao magistrado. No caso da ADIn baiana (ADIn $\mathrm{n}^{\circ}$ 030348940.2012.8.05.0000), o que chama atenção é ter ganhado notoriedade nos meios de comunicação locais por conta das disputas entre os diversos setores sociais e agentes políticos e econômicos, ensejando, desse modo, adentrar no feito por intermédio do amicus curiae, figura processual que permite a intervenção assistencial de entidades representativas em processo de controle de constitucionalidade. Embora tecnicamente não configurassem como parte, mediante o amicus curiae, tais setores sociais e agentes políticos e econômicos buscaram influenciar os magistrados, 
alegou "falta de interesse processual do Ministério Público na propositura da demanda, bem assim que os dispositivos impugnados se encontram inseridos na Lei de Ordenamento do Uso e da Ocupação do Solo (LOUOS), que detém natureza de lei ordinária e que não está sujeita a processo legislativo especial.” À unanimidade de votos, o Tribunal rejeitou a preliminar por falta de interesse processual do Ministério Público arguida pela ADEMI.

Em seguida, a Federação das Associações de Bairros de Salvador - FABS requereu sua habilitação como amicus curiae, pugnando pela procedência da ação. Aduziu que houve prejuízo para a participação popular na alteração do aludido plano diretor, como se pode inferir:

[...] as alterações da LOUOS por meio de emendas que eram destinadas ao PDDU infringem diretamente 0 Estatuto das Cidades e toda a ordem jurídica posta na Constituição do Estado da Bahia, já que teve como fulcro burlar toda a participação popular no projeto, e exclui o caráter deliberativo do Conselho Municipal do Meio Ambiente, passando a tratá-lo como órgão meramente opinativo sem qualquer força decisória na deliberação e avaliação dos projetos a serem executados no Município. (TJ/BA, 2014, p. 7).

Posteriormente, sob o argumento da ausência de "ampla e efetiva participação popular", dentre outras justificativas, o Conselho Regional de Engenharia e Agronomia da Bahia - CREA/BA requereu sua habilitação no feito, que foi deferida. Na mira dos desdobramentos políticos da questão, o Estado da Bahia requereu sua intervenção no feito, como amicus curiae, defendendo a inconstitucionalidade dos dispositivos impugnados, logo, pugnando pela procedência da ação.

Pedidos de ingressos no feito também foram formulados pela Ordem dos Advogados do Brasil, Seção Bahia - OAB/BA, pelo Instituto de Arquitetos do Brasil, Departamento Bahia - IAB/BA, pelo Conselho de Arquitetura e Urbanismo da Bahia - CAU/BA, pelo Sindicato de Arquitetos e Urbanistas do Estado da Bahia -

através da apresentação de peças técnicas, dossiês e sustentação oral durante o processo de julgamento. 
SINDARQ/BA e pela Sociedade Brasileira de Urbanismo - SBU, pedidos esses todos aceitos pelo Tribunal. Em síntese, a OAB/BA, alegando que os mecanismos de participação popular que integravam a legislação municipal foram observados, manifestou-se "pela improcedência da declaração de inconstitucionalidade fundamentada na ofensa aos arts. 60 e 64 da Constituição Estadual” (TJ/BA, 2014, p. 12). Por seu turno, o IAB/BA, o SINDARQ/BA e o CAU/BA, em manifestação conjunta, trouxeram "aos autos parecer técnico sobre a Lei n. 8.167/2012, e pugnando pela declaração de inconstitucionalidade dos dispositivos impugnados." (TJ/BA, 2014, p. $15)$.

No julgamento do mérito, inicialmente o Tribunal recorreu à decisão do Supremo Tribunal Federal (STF), para ensejar a sua competência acerca da apreciação do feito, e, depois de invocar dispositivos da Constituição Federal, da Constituição da Bahia e do Estatuto da Cidade, declarou a estrita consonância ou sintonia entre os precitados diplomas legais quanto à garantia de participação popular nos processos de elaboração de leis que tratem de políticas urbanísticas (TJ/BA, 2014, p. 33-35). Com referência ao tema, válidas são as palavras do relator do feito:

Aliás, à luz dos dispositivos indicados e dos princípios constitucionais da democracia participativa e da participação democrática nas políticas urbanas, têm-se entendido, invariavelmente, pela necessidade de ampla e efetiva participação popular no processo de elaboração e aprovação de leis que instituam ou alterem o Plano Diretor dos Municípios. Por esta razão, as Cortes estaduais vêm adotando posicionamento uníssono de que é inconstitucional norma municipal que altera o Plano Diretor sem a efetiva participação da comunidade no processo legislativo (TJ/BA, 2014, p. 35). (Com grifo no original).

Defendendo, novamente, a necessidade de ampla e efetiva participação popular, mediante canais ou mecanismos que possibilitem o envolvimento de diversos membros da comunidade em questões urbanísticas que cuidem da melhoria da qualidade de vida dos habitantes das cidades, o relator explicitou o seguinte: 
Portanto, resta indene de dúvida que é indiscutível a necessidade de ampla participação popular, inclusive com debates envolvendo os mais diversos membros da comunidade, para a elaboração ou alteração do Plano Diretor, e isto deve ocorrer para que a população pense e discuta os problemas da cidade onde mora.

Bem por isso, a tarefa de planejar a cidade passa a ser função pública que deve ser compartilhada pelo Estado e pela sociedade, corresponsáveis pela observância dos direitos humanos e pela sustentabilidade dos processos urbanos.

Não por outra razão, a gestão democrática é o método proposto pela lei para conduzir a política urbana. Deste postulado não devemos nos afastar, já que o Plano Diretor assume contorno de instrumento fundamental para a realização do direito à cidade. Sem hesitação, construído de forma democrática e participativa é ele que irá trazer para a realidade os anseios e desejos das diferentes regiões e classes da urbe. (TJ/BA, 2014, p. 38).

Como exorta esse julgado, é indiscutível a necessidade de ampla participação popular na elaboração do plano diretor como instrumento fundamental para a concretização do direito à cidade, cujo planejamento deve ser compartilhado entre o Estado e a sociedade, mediante gestão democrática. Daí deriva a compreensão acerca da importância da representação popular não apenas para a formatação, mas também para alteração, do plano diretor municipal, consubstanciado em lei.

$\mathrm{Na}$ apreciação da matéria em foco, por intermédio da análise da documentação acostada, inclusive, atas das supostas audiências realizadas, foi suficiente para o Tribunal concluir que a necessária participação popular não foi garantida quando da elaboração da Lei 8.167/12. Houve, na prática, singela participação popular, pois a realização das audiências não tinha sido publicizada com a devida antecedência e pelos meios adequados, e não foi disponibilizado o acesso aos estudos técnicos necessários ou a quaisquer documentos que tenham servido de apoio para a elaboração do projeto de lei que deu origem à norma impugnada. (TJ/BA, 2014, p. 42).

Até mesmo pelo decurso do lapso temporal inferior a 1 (um) mês entre o recebimento do Projeto de Lei e a respectiva promulgação da Lei 8.167/2012, o Tribunal entendeu ser questão de razoabilidade e lógica concluir que não foi atendido o devido processo legislativo 
especial exigido para a alteração do Plano Diretor. O órgão julgador, igualmente, acrescentou que situações ainda mais graves ocorreram durante a elaboração das Leis 8.378/12 e 8.379/12, quando não foi identificado nem comprovado algum tipo de participação popular. (TJ/BA, 2014, p. 42-44).

De modo fundamentado, o Tribunal concluiu o julgamento reconhecendo o imperioso interesse público evidenciado ao longo do trâmite processual e declarou a inconstitucionalidade de vários dispositivos da Lei Municipal 8.167/2012, bem assim, em sua integralidade, os das Leis 8.378/12 e 8.379/12. (TJ/BA, 2014, p. 45).

\section{A RACIONALIDADE NEOLIBERAL COMO FIO CONDUTOR DAS POLÍTICAS PÚBLICAS NA ÁREA URBANÍSTICA}

Para discutir a participação popular e a democracia representativa, sob esse ângulo, as relações de poder daí decorrentes, recorre-se, inicialmente, ao conceito de política pública formulado por Friedberg (1993, p. 26), para quem política pública corresponde a

\section{[...] um conjunto político relativamente autônomo que opera ao seu nível a regulação dos conflitos entre os interessados e que assegura a articulação e o ajustamento dos seus interesses e dos objetivos individuais entre eles, assim como dos interesses e objetivos coletivos.}

Nessa definição, Friedberg articula a política pública e o político, ou seja, as políticas públicas se articulam com a política no sentido geral, e, enquanto tal, dependem fundamentalmente do político para virem a corresponder estruturalmente aos interesses da coletividade. A referência ao político parece ser indispensável à fundamentação legítima das políticas públicas na atualidade. Igualmente, parece inequívoco que a política dita democrática liberal ou a democracia participativa é uma espécie de emblema, um truísmo incontestável, que fundamenta o sistema simbólico de legitimação do próprio poder político. 
Como envolvem relações de poder, as políticas públicas, que podem oferecer conteúdo ou servir de substância às ações governamentais, precisam passar por constantes processos avaliativos e de renovação na senda da relação entre o político democrático e a política, de onde decorram ações públicas que garantam bens e serviços públicos de qualidade às múltiplas instâncias da vida em comum, vez que deve estar assentada na vontade geral que funda e expressa a soberania popular a ser frequentemente reconstruída. Há a necessidade de que as políticas públicas, como arenas discursivas, espaços políticos de debates, estejam em constante (re)negociação e aprendizagem quanto à tomada de decisões que deem sentido e sustentação à ação governamental, como advertem Muller e Surel (2002).

Quando da apreciação da referida ADI pelo Tribunal, restou demonstrada a atuação de vários sujeitos ou agentes que disputam processos de (re)produção e apropriação da cidade, o que acaba inviabilizando o efetivo envolvimento da população em questões correlacionadas às problemáticas urbanísticas. Infelizmente, as raras decisões alicerçadas na participação da população no processo de elaboração e aprovação do Plano Diretor de Salvador entrelaçaram-se com as articulações de posições, de interesses e conflitos políticos, por vezes, antagônicos em relação às necessidades e interesses da coletividade.

Em tom bastante crítico, Bonizzato e Coutinho (2011, p. 25) são reticentes quanto à "suposição da possibilidade de mudança da sociedade pela edição e aplicação de boas leis”. Na perspectiva de que há poucas possibilidades e potencialidades de respostas legais para solucionar problemáticas urbanísticas, Bonizzato e Coutinho (2011, p. 41-42) esclarecem que, a despeito do diagnóstico da designada "crise urbana", esta não tem o significado de "patologia social", a depender de correção "com a terapia da racionalidade técnica (leia-se planejamento urbano) ou com as virtudes da gestão democrática, mas tão somente a própria realização da ordem determinadas pela lógica 
do capital", acentuando os referidos autores que essa lógica "torna impensável que empresários aceitem reduzir a taxa de lucro de suas empresas em benefício da adoção de tecnologias e processos de produção capazes de operar a diminuição de danos ambientais" e, no mesmo sentido, "que os detentores do capital imobiliário abram mão de seus projetos em nome de interesses coletivos". Essa realidade toda impacta prejudicialmente o instituto da representação popular enquanto instrumento da política urbana.

O forte arsenal normativo e institucional que ampara o direito à participação popular na gestão da cidade não é suficiente para barrar a lógica mercadológica que, em grande medida, guia a atuação do Poder Público no que se refere aos espaços urbanos, havendo, assim, um descompasso entre arranjos políticos e a realidade urbanística brasileira. Em razão disso, Oliveira Filho (2009, p. 69) critica o modelo deliberativo: "[...] as pesquisas sociais recentes têm revelado os espaços deliberativos como estruturas competitivas controladas por grupos de poder e mercado". Segundo o autor, há um "monopólio da comunicação" da política, de modo que o desequilíbrio da comunicação é mais uma causa do desinteresse político e da debilidade da participação popular (OLIVEIRA FILHO, 2009). Nesse sistema democrático, há uma luta entre os cidadãos que possuem e os que não possuem o "código". Assim, estes últimos são automaticamente excluídos dos debates que decidem as questões da política urbanística. Esse código pode ser uma posição social mais importante ou até a própria dificuldade no entendimento da lei e quanto à sua aplicação. Nessa direção, Villaça também desenvolveu acuradas análises em torno do caráter ideológico e manipulador dos planos diretores no Brasil (VILLAÇA, 2005). Friedberg (1993) considera que a liberdade de ação das pessoas é limitada pelas condições materiais e sociais que prevalecem no seu contexto de ação e que são escoradas por um conjunto de estruturas e de regulações globalizantes relacionadas à cultura. 
Identificou-se, por outro lado, a superficialidade na aplicação dos instrumentos previstos no Estatuto da Cidade5, em particular a utilização da participação popular na famigerada gestão democrática da cidade, enquanto forma de controle social e mecanismo de prevenção da corrupção e fortalecimento da cidadania.

$\mathrm{O}$ que restou comprovado na análise do julgamento ADI baiana foi um arremedo do direito à participação popular, que ainda não se incorporou nem foi assimilada aos debates políticos pelos grupos de poder e pela sociedade em geral. Não configura novidade, desse modo, que a democracia liberal representativa, segue operando como suposta esfera política ideal, obedecendo regras ditadas por setores econômicos e financeiros hegemônicos. Em ocorrendo o ceticismo político, o esvaziamento ou comprometimento de sentido e de conteúdo da aludida democracia, é forçoso, em conformidade com a ideia do bem comum, defender a refundação dos debates de cunho democráticos e, logo, da soberania do povo brasileiro. Não é exagero, deveras, considerar a soberania popular como central para o debate atual ou contemporâneo respeitante à construção de instituições democráticas, livres e igualitárias.

Isso significa igualmente a necessidade de repensar em que consiste o direito de participar, pois, idealmente, a participação é um

5 Entre as diretrizes gerais para a política urbana traçadas pelo Estatuto da Cidade, ressalta-se o disposto em seu artigo $2^{\circ}$, inciso II, que versa sobre a necessária participação popular nas demandas urbanísticas de interesse da coletividade. De acordo com esse dispositivo é diretriz geral da política urbana a garantia da gestão democrática da política urbana, a ser obtida mediante "a participação da população e de associações representativas dos vários segmentos da comunidade na formulação, execução e acompanhamento de planos, programas e projetos de desenvolvimento urbano". O Estatuto da Cidade reservou todo o seu Capítulo IV para tratar da Gestão Democrática da Cidade, dispondo no artigo 43 que a garantia da participação da população nessa gestão se dará, dentre outros critérios ou mecanismos, mediante a organização de órgãos colegiados de política urbana e de conferências sobre assuntos de interesse urbano, instrumentos estes a serem desenvolvidos nos três (três) entes federativos (incisos I e III), debates, audiências e consultas públicas (inciso II), e iniciativa popular de projetos de lei e de planos, programas e projetos de desenvolvimento urbano (inciso IV). O artigo não é exaustivo, deixando em aberto a possibilidade da utilização de quaisquer outros meios de participação popular que se façam necessários. Observa-se que as formas de participação popular previstas no Estatuto da Cidade são bem amplas e indicam possibilidades de várias estratégias ou metodologias serem utilizadas simultaneamente. 
instrumento para se conseguir uma das expressões mais amplas de democracia direta, o que sugere que o arranjo de uma política de participação popular bem sedimentada envolve muito mais que a observação de alguns procedimentos pré-estabelecidos ou de um estudo técnico. Implica, na verdade, o compromisso político de criar um processo amplo e irrestrito que permita que os múltiplos segmentos sociais que habitam as cidades possam interagir com os gestores municipais referentemente às questões urbanas de interesse da coletividade. O poder público deve conduzir esse processo de forma plenamente transparente, descentralizado e participativo e seus desideratos e ações devem ser explícitos e que visem ao bem-comum.

Constatou-se, mediante a análise do julgamento da ADI baiana, que o planejamento urbano da cidade de Salvador foi substituído pela imposição de atender interesses voltados para a lógica mercadológica, sobretudo imobiliária, de (re)produção e utilização do espaço urbano, o que certamente fragiliza ou coloca em xeque toda a legislação protetora de direitos urbanísticos, e, consequentemente, fragiliza as políticas públicas urbanísticas, o que se reflete, também, como incapacidade institucional dos gestores municipais de regulamentar e aplicar a dita legislação e os instrumentos jurídicosurbanísticos aptos para esse fim sejam timidamente aplicados.

Em suma, frente à complexidade da sociedade contemporânea, pode-se dizer que, no que pese estar presente, no ordenamento jurídico brasileiro, todo um arsenal legislativo necessário para que seja garantido o direito à participação popular na gestão da cidade, evidenciou-se, no âmbito da administração municipal de Salvador um quadro de evidentes problemas e obstáculos estruturais de implementação desse direito. Verificou-se frontal e sistemática violação do direito à participação pelos gestores públicos, o que reafirma a concepção hegemônica de democracia que restringe a prática democrática ao conjunto de regras de procedimentos para a formação de decisões coletivas.

Decerto, os casos de corrupção sistêmica que aflige as sociedades contemporâneas exigem melhores mecanismos para 
cobrar uma gestão responsável dos agentes estatais, sendo o controle social o único mecanismo capaz de promover a responsabilização de governantes descompromissados com a população (ASSIS e SILVA, 2017, p. 2). Contudo, como bem anotam Assis e Silva (2017, p. 2), em suas ponderações, o "controle social não deve ser um simples elemento procedimental sem aptidão para interferir na gestão estatal; ao contrário, precisa ser eficaz para proporcionar a responsabilização dos maus gestores", acentuando aqueles autores que "deve ser feito por cidadãos informados sobre os assuntos estatais e também sobre seus direitos, especialmente os direitos de participação”. Como corolário, há que se considerar importante esse controle para a efetividade da participação popular nas discussões atinentes à política urbana.

Diante da real significância da participação popular nas decisões governamentais, observa-se uma nítida separação ou distanciamento entre o Estado e o indivíduo, pois as instâncias de mediação política por meio da representatividade criam mecanismos de entrelaçamento entre o Estado e segmentos economicamente fortes. Vigora um modelo político baseado na vontade de um grupo dominante, mas travestido como democracia e expressão de toda a sociedade.

Prevalece a homogeneização da concepção de que o Estado democrático reconhece e garante uma ampla liberdade individual e acolhe a vontade da maioria, expressa por meio do voto. Dotadas de ampla liberdade individual conferida a elas pelo Estado democrático, as pessoas são inclinadas a buscar a consecução dos seus interesses pessoais, sendo isso suficiente para obterem as melhorias que desejam para suas vidas. Essa lógica do capitalismo neoliberal faz com que as pessoas adotem uma postura passiva, como meras coadjuvantes no processo político, deixando as decisões políticas a cargo de seus representantes no Legislativo e ao Executivo para se atingir um ideal político falsamente consensual.

O falso discurso da igualdade democrática fundada na autonomia de ação individual vincula-se ao projeto do capitalismo 
neoliberal, para quem a liberdade individual funde-se com a liberdade à livre iniciativa econômica. Isso gera um imobilismo político ou uma falsa cidadania, que amputa ou diminui sensivelmente a capacidade ou possibilidade de garantir direitos à coletividade, em razão da transcendência de finalidades políticas alheias ao sujeito, que é supostamente a fonte originária e destinatária de toda positivação de direitos.

No caso da reformulação do Plano Diretor de Salvador, o fato ganhou notoriedade, porque se tratava de uma política pública que impactaria diretamente na ação do capital, razão pela qual emergiram disputas em torno do respectivo processo participativo, que adquiriu um caráter conflituoso, quando sugiram agenciamentos sociais e subjetividades que não passaram pelo crivo de arenas democráticas capazes de criar as condições necessárias ao confronto de diferentes pontos de vistas e a síntese dos argumentos da população baiana. O exame da referida ADI enseja a percepção de, na prática, ter havido um verdadeiro simulacro de participação popular, situação designada pelo relator do feito como "singela participação popular".

Observou-se que o direito à participação popular foi reduzido a mera figura retórica, uma verdadeira ilusão ou engano, abstração no plano fático, uma esfera que atomiza a representação do interesse público em atendimento à lógica do neoliberalismo. Isso significa que a dimensão do social está afastada do político. Se a dimensão social é esvaziada de conteúdo político, certamente os indivíduos terão mais dificuldades ou são diminuídas suas possibilidades de reivindicar e garantir direitos. Significa, também, que os gestores públicos acolherem sem reservas os interesses e necessidades do mercado, um dos pilares da governamentalidade capitalista, "da nova arte de governar" de cunho neoliberal tal como descrita por Foucault (2008), na sua obra Nascimento da Biopolítica, uma diretriz político-estatal que compõe o saber-poder contemporâneo. 


\section{CONSIDERAÇÕES FINAIS}

É pública e notória a crise de legitimidade pela qual vem passando a atual concepção hegemônica de democracia que restringe a prática democrática ao conjunto de regras de procedimentos para obter decisões coletivas, colocando em dúvida, por via oblíqua, o próprio modelo de representação política, logo, ultrapassando o sentido de cidadania restrita ao exercício do voto. É real a percepção de que a democracia representativa ou liberal está fragilizada.

Conforme Safatle (2012), essa crise decorre do esgotamento do modelo de democracia parlamentar liberal, no qual as pessoas não se sentem mais representadas e passam a manifestar-se de diversas formas, exigindo uma democracia real que perpasse pelo transbordamento da política da esfera estatal e valorização da soberania popular.

Nesse contexto, faz-se necessária reflexão, à toda evidência, em torno das conquistas, disputas e desafios do planejamento e gestão de cidades, que resultem na democratização dos bens, recursos, equipamentos e serviços (re)produzidos e disponibilizados à sociedade e problematizar no que tange às contingências da capacidade de acesso a esses bens localizados nos espaços urbanos por distintos grupos sociais, em particular pelos segmentos mais vulneráveis, que mais sofrem com os impactos nefastos das segregações socioespaciais decorrentes do processo de urbanização capitalista contemporânea, resultado da (re)produção ampliada do capital que se perpetua ou se refaz na continuação de tais desigualdades, e, na maioria das vezes, conta com a colaboração de gestores públicos. Presencia-se que após mais de 15 (quinze) anos de sua vigência, o Estatuto da Cidade ainda não foi capaz de sobrepor-se à lógica reinante que orienta a (re)produção do espaço urbano, elemento material essencial à lucratividade permanente do capital econômico e financeiro.

Originou-se, desse modo, um visível paradoxo ou descompasso entre teoria e prática, entre lei e realidade social. 
Seguramente, a cidade idealizada pela ordem jurídico-urbanística brasileira não é a mesma cidade que os habitantes vivenciam ou experimentam cotidianamente. São inúmeros obstáculos, desafios e fragilidades contidas no próprio Estatuto da Cidade, que impõe limites à democratização da ordem jurídico-urbanística brasileira, desdobrando-se na falta de efetividade ou no déficit de implementação do rol exemplificativo de direitos contidos no art. $2^{\mathrm{o}}$, I, do aludido Estatuto, a exemplo dos direitos à mobilidade, moradia, infraestrutura urbana e saneamento ambiental etc.

Verificou-se que o simples fato de existirem mecanismos ou instâncias formais de participação popular não é suficiente e não garante o envolvimento da população e a qualidade participativa; antes serve mais para a validação e legitimação, sob o selo democrático, de práticas definidas como desejáveis por setores hegemônicos. Diante dessa afirmação, identificou-se um problema de gestão das cidades, muitas vezes excludente, embora com o nome de "participativo", devido à obrigatoriedade legal de participação. Ao que tudo indica, certamente, a participação no processo de planejamento permanece limitada e subordinada aos interesses econômicos e políticos partidários, em detrimento dos interesses coletivos.

No caso da ADI baiana, se, por um lado, restou evidenciado que os instrumentos jurídico-urbanísticos foram timidamente aplicados, por outro, registra-se que a atuação ampla de diversos movimentos sociais foi decisiva para reverter parte dos efeitos da aprovação da Lei 8.167/2012, que provocou mudanças substanciais no Plano Diretor de Salvador, vez que tais movimentos encaminharam essa demanda via representação ao Ministério Público do Estado da Bahia, com o fito de invalidar o novo Plano Diretor.

Com embasamento na representação feita por tais movimentos sociais, o Ministério Público do Estado da Bahia ajuizou a precitada ADI, alegando, para tanto, que a ausência de participação popular no processo de elaboração de normas jurídicas que alteraram radicalmente o mencionado Plano contrariava o princípio da democracia participativa, na medida em que não oportunizava o 
Racionalidade Neoliberal E Política Pública Urbanística Frente Ao Direito De...

necessário debate com a sociedade, o que não deixa de ser uma crítica aos processos representativos, que enseja a necessidade do exercício de outra democracia que passe pela afirmação e criação de direitos, por meio da construção dos sujeitos sociopolíticos, por sua própria ação, ultrapassando o sentido restrito de cidadania.

$\mathrm{Na}$ análise da crise da democracia representativa, é fundamental compreender o espaço urbano sob o enfoque do neoliberalismo e perceber como ele se constitui enquanto um território de lutas e de (re)produção de redes de interesses que agem, na maioria das vezes, em detrimento do bem comum.

Data de Submissão: 22/02/2018

Data de Aprovação: 17/12/2019

Processo de Avaliação: double blind peer review

Editor Geral: Jailton Macena de Araújo

Editor de Área: José Ernesto Pimentel Sobrinho

Assistente Editorial: Bruna Agra de Medeiros

\section{REFERÊNCIAS}

ASSIS, Christiane Costa; SILVA, Adriana Campos. Controle social e responsabilidade estatal. In: Prima Facie, João Pessoa: PPGCJ, v. 16, n. 33, 2017, p. 1-22. Disponível em:

http://periodicos.ufpb.br/index.php/primafacie/article/view/35721. Acesso em: 8 fev. 2018.

AVRITZER, Leonardo. Reforma política e participação no Brasil. In: AVRITZER, Leonardo; ANASTASIA, Fátima (Orgs.). Reforma política no Brasil. Belo Horizonte: UFMG, 2007. p. 35-44.

BOURDIEU, Pierre. Espíritos de Estado: gênese e estrutura do campo burocrático. In: BOURDIEU, Pierre. Razões Práticas: Sobre a teoria da ação. Campinas: Papirus, 2011, p. 91-135.

\section{BRASIL. Constituição da República Federativa do Brasil de}

1988. Disponível em: 
http://www.planalto.gov.br/ccivil 03/constituicao/constituicaocom pilado.htm. Acesso em: 28 jan. 2018.

BRASIL. Lei no 10.257, de 10 de julho de 2oo1. Regulamenta os arts. 182 e 183 da Constituição Federal, estabelece diretrizes gerais da política urbana e dá outras providências. Disponível em:

http://www.planalto.gov.br/ccivil 03/leis/LEIS 2001/L10257.htm. Acesso em: 20 jan. 2018.

COUTINHO, Ronaldo; BONIZZATO, Luigi (Org.). Direito da cidade: novas concepções sobre as relações jurídicas no espaço social urbano. 2. ed. Rio de Janeiro: Lumen Juris, 2011.

FOUCAULT, Michel. Em defesa da sociedade: curso no Collège de France (1975-1976). São Paulo: Martins Fontes, 2005.

FOUCAULT, Michel. O nascimento da biopolítica: curso dado no Collège de France (1978-1979). São Paulo: Martins Fontes, 2008.

FREITAS FILHO, Roberto; LIMA, Thalita Moraes. Metodologia de Análise de Decisões - MAD. Univ. JUS, Brasília, n. 21, p. 1-17, jul./dez. 2010. Disponível em:

https://edisciplinas.usp.br/pluginfile.php/4318159/mod_resource/c ontent/1/metodologia\%2ode\%2oanalise\%2ode\%2odecisoes.pdf. Acesso em: 24 mar. 2020.

FRIEDBERG, Erhard. O Poder e a Regra: Dinâmicas da Ação Organizada. Tradução de Armando Silva. Lisboa: Instituto Piaget, 1993.

GIDDENS, Antony. Consequências da Modernidade. São Paulo: Unesp, 1991.

HOBBES, Thomas. Leviatã ou a matéria, forma e poder de um estado eclesiástico e civil. $4^{\text {a }}$ ed. São Paulo: Nova Cultural, 1988.

DIDIER JUNIOR, Freddie. Curso de Direito Processual Civil: Teoria Geral do Processo e Processo de Conhecimento. $12^{\mathrm{a}}$ Edição, Editora JusPodium. Salvador, 2010.

LOCKE, John. Ensaio Acerca do Entendimento Humano. [Os Pensadores]. São Paulo: Editora Nova Cultural, 1983.

MARIOTTI, Alexandre Abel; FERNANDES, Bruna Souza; LUNELLI, Carlos Alberto. Participação popular e poder judiciário: uma possibilidade para a proteção ambiental. In: Prima Facie. João Pessoa: PPGCJ, v. 17, n. 34, 2018. Disponível em: https://periodicos.ufpb.br/ojs/index.php/primafacie/article/view/3 0391. Acesso em: 9 out. 2019. 
MACPHERSON, Crawford Brough. The political theory of possessive individualism: Hobbes to Locke. Oxford: Oxford University Press, 1962. (Edição em português: A Teoria Política do individualismo Possessivo. Trad. Nelson Dantas, Rio de Janeiro: Paz e Terra, 1979.)

MULLER, Pierre; SUREL, Yves. A Análise das Políticas

Públicas. Traduzido por Agemir Bavaresco e Alceu R. Ferraro. Pelotas: Educat, 2002.

Novas referencias

NUNES, Débora. Por uma pedagogia da participação popular: trabalhando com comunidades. $1^{\mathrm{a}}$ reimpressão. Salvador: UNESCO/Quarteto, 2006. Disponível em: http://cirandas.net/articles/o028/2912/pedagogia da participacao. pdf. Acesso em 10 jan. 2018.

OLIVEIRA FILHO, João Telmo. A participação popular no planejamento urbano: a experiência do Plano Diretor de Porto Alegre. 2009. 332 f. Tese (Doutorado em Planejamento Urbano e Regional) - Universidade Federal do Rio Grande do Sul, Porto Alegre, 2009.

SAFATLE, Vladimir. Amar uma ideia. In: HARVEY, David et al. Occupy: movimentos de protestos que tomaram as ruas. São Paulo: Boitempo/Carta Maior, 2012, p. 45-55.

SILVA, Frederico Barbosa da; JACCOUND, Luciana; BEGHIN, Nathalie. Políticas sociais no Brasil: Participação Social, Conselhos e Parcerias. In: JACCOUND, Luciana (Org.). Questão Social e Políticas Sociais no Brasil contemporâneo. Brasília: IPEA, 2005. Disponível em: http://www.ipea.gov.br/agencia/images/stories/PDFs/livros/Livro Questao Social.pdf. Acesso em: 5 fev. 2018.

TEIXEIRA, Diego Monte; ALBUQUERQUE, Newton Menezes. A participação popular na governança da água como reforço à cidadania ambiental nas democracias da América Latina. In: Prima Facie. João Pessoa: PPGCJ, v. 17, n. 34, 2018. Disponível em: https://periodicos.ufpb.br/ojs/index.php/primafacie/article/view/3 5776. Acesso em: 9 out. 2019.

TRIBUNAL DE JUSTIÇA DO ESTADO DA BAHIA. Ação Direta de Inconstitucionalidade no $0303490-40.2012 .8 .05 \cdot 000$. Requerente: Procurador Geral de Justiça do Ministério Público da Bahia. Réu: Município do Salvador. Relator: Desembargador José Edivaldo Rocha Rotondano. Sessão Plena do Tribunal. Salvador,12 de fev. 2014 . 
VILLAÇA, Flávio. As ilusões do plano diretor. São Paulo, Edição do autor, 2005. Disponível em:

http://www.flaviovillaca.arq.br/pdf/ilusao_pd.pdf. Acesso em: 3 fev. 2018.

WOOD, Ellen Meiksins. Democracia contra Capitalismo: a renovação do materialismo histórico. São Paulo: Boitempo, 2003. 
Neoliberal Rationality And Urban Public Policy Against The Right To Popular Participation: An Analysis Of ADI O303489-40.2012.8.05.0000

\author{
Domingos do Nascimento Nonato
}

Raimundo Wilson Gama Raiol

\author{
Romário Edson da Silva Rebelo
}

\begin{abstract}
In a very appropriate sociopolitical moment, of redefining the practical notion of representation and popular sovereignty, it is reflected about the participation of society in urban public policies as an exercise of that sovereignty. As an innovative arena or channel for the involvement of the general population in political decision-making, in various spheres of governmental action, this participation corresponds, in practice, to a mechanism that serves only to validate and legitimize the political and economic interests that proliferate in public levels. and private, even in the hegemonic sectors, particularly in the market. It uses the qualitative approach, the bibliographic and documentary analysis, especially ADI $\mathrm{n}^{\mathrm{o}}$ 0303489-40.2012.8.05.0000, judged, at the beginning of 2014, by the TJ / BA, which decided for the partial and general unconstitutionality of the laws of the city of Salvador. Master Plan altered, without guaranteeing broad and effective popular participation. It is assumed that this participation, resulting from and direct expression of popular sovereignty, does not automatically configure itself in a political arena capable of providing opportunity and consolidating democratic practices of public management. Popular sovereignty functions as an ideological subterfuge or artificial mechanism that masks the true face of neoliberal-capitalist domination translated into state action, which, as a rule, is permeated by the interests of private sectors.
\end{abstract}

Keywords: Neoliberal rationality. Urbanistic public policies. Participation. Popular sovereignty.

DOI: https://doi.org/10.22478/ufpb.1678-2593.2021v20n44.38373

Conteúdo sob licença Creative Commons: Attribuition-NonCommercial-NoDerivative 4.o International (CC BY-NC-ND 4.0)

(c)) EY-NG-ND 